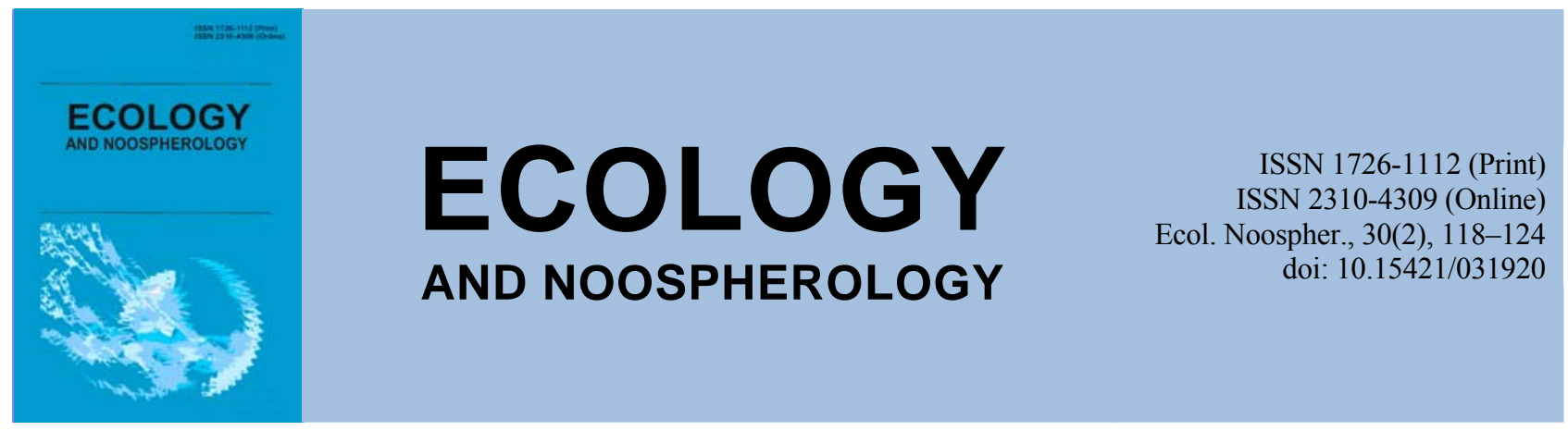

\title{
Lipids peroxidation of wood plants seedlings under the volatile organic compounds action
}

\author{
E. G. Tyulkova, L. P. Avdashkova \\ Belarusian trade and economic university of consumer cooperatives, Gomel, Belarus
}

Article info

Received 03.09.2019

Received in revised form

11.09.2019

Accepted 20.09.2019

Belarusian trade and economic university of consumer cooperatives,

pr. October, 50, Gomel, 246029, Belarus.

Tel.: +375-29-316-44-83

E-mail: tut-3@mail.ru
Tyulkova, E. G. Avdashkova, L. P. (2019). Lipids peroxidation of wood plants seedlings under the volatile organic compounds action. Ecology and Noospherology, 30(2), 118-124. doi:10.15421/031920

One of the criteria for plant adaptation to the volatile organic compounds action can be the lipid peroxidation intensity processes as a result of destructive oxidative processes ratio and the plants activity antioxidant protection. In this regard, the aim of the study was a comparative study of volatile various doses organic compounds effect (o-xylol, benz(a)pyrene, butyl acetate) on the content of malondialdehyde (MDA) in woody plants seedlings under specified experimental conditions. The results of an experiment on processing leaf blades of urban environments woody plants seedlings with volatile hydrocarbons and their mixture indicate that the effect of o-xylol, butyl acetate and a mixture of butyl acetate and o-xylol on the malonic dialdehyde content in drooping birch Betula pendula Roth. during the first days after exposure, it was manifested in the accumulation of lipid peroxidation products, whereas after three days of the experiment, the plant response in this case was expressed as a decrease in the content of MDA and the intensity of the lipid peroxidation process. Benz(a)pyrene in drooping birch caused a higher content of MDA three days after treatment. In the pyramidal poplar, the character of o-xylol influence and a butyl acetate and o-xylol mixture over the experiment course was similar to the drooping birch and was expressed in the lipid peroxidation products accumulation one day after treatment. Benz(a)pyrene was the cause of the increased malondialdehyde content one day after treatment, butyl acetate - after three days of the experiment. The combined processing of birch seedlings leaf blades with a butyl acetate and o-xylol mixture made it possible for these compounds to enhance each other's toxic effect compared to their action alone, with the exception of o-xylol three days after treatment with the mixture in the maximum dose. In pyramidal poplar, unlike birch, suspended butyl acetate in the mixture weakened the o-xylol toxic effect in comparison with its effect in the form of a single solution, and o-xylol weakened the effect of butyl acetate. In general, in the studied wood seedlings, the most potent compounds one cluster in the processes of membrane lipid peroxidation compared with the control can include benz(a)pyrene (in birch), butyl acetate and a mixture of butyl acetate and o-xylol (at the poplar pyramidal).

Keywords: malondialdehyde; drooping birch seedlings Betula pendula Roth.; pyramidal poplar seedlings Populus pyramidalis Roz.; o-xylol; benz(a)pyrene; butyacetate

\section{Перекисне окислення ліпідів саджанців деревних рослин при дії летких органічних сполук}

\author{
О. Г. Тюлькова, Л. П. Авдашкова
}

Білоруський торговельно-економічний університет споживчої кооперачії, Гомель, Білорусь

У статті представлено результати визначення вмісту малонового діальдегіду (МДА) в листі саджанців одних із найбільш поширених представників деревних рослин міського середовища - берези повислої Betula pendula Roth. i тополі пірамідальної Populus pyramidalis Roz. - у задаваних умовах експерименту. Установлено, що вплив о-ксилолу, бутилацетату і суміші бутилацетату з о-ксилолом на вміст малонового діальдегіду у берези повислої проявлявся в накопиченні МДА протягом першої доби після впливу, бенз(а)пірену - через три доби після обробки. У тополі пірамідальної характер впливу о-ксилолу, бенз(а)пірену і суміші бутилацетату з о-ксилолом виявлявся в накопиченні продуктів перекисного окислення 
ліпідів (ПОЛ) через одну добу після обробки, бутилацетату - через три доби досвіду. У цілому в досліджуваних деревних саджанців в один кластер найбільш сильно діючих з'єднань на процеси ПОЛ у порівнянні 3 контролем можуть бути віднесені бенз(а)пірен (у берези повислої), бутилацетат і суміш бутилацетату з о-ксилолом (у тополі пірамідальної).

Ключові слова: малоновий діальдегід; саджанці берези повислої Betula pendula Roth.; саджанці тополі пірамідальної Populus pyramidalis Roz.; о-ксилол; бенз(а)пірен; бутилацетат

\title{
Перекисное окисление липидов саженцев древесных растений при действии летучих органических соединений
}

\author{
Е. Г. Тюлькова, Л. П. Авдашкова
}

Белорусский торгово-экономический университет потребительской кооперации, Гомель, Беларусь

В статье представлены результаты определения содержания малонового диальдегида (МДА) в листьях саженцев одних из наиболее распространенных представителей древесных растений городской среды - березы повислой Betula pendula Roth. и тополя пирамидального Populus pyramidalis Roz. - в задаваемых условиях эксперимента. Установлено, что влияние о-ксилола, бутилацетата и смеси бутилацетата с о-ксилолом на содержание малонового диальдегида у березы повислой проявлялось в накоплении МДА в течение первых суток после воздействия, бенз(а)пирена - через трое суток после обработки. У тополя пирамидального характер влияния о-ксилола, бенз(а)пирена и смеси бутилацетата с о-ксилолом выражался в накоплении продуктов перекисного окисления липидов (ПОЛ) через одни сутки после обработки, бутилацетата через трое суток опыта. В целом у исследуемых древесных саженцев в один кластер наиболее сильно действующих соединений на процессы ПОЛ по сравнению с контролем могут быть отнесены бенз(а)пирен (у березы повислой), бутилацетат и смесь бутилацетата с о-ксилолом (у тополя пирамидального).

Ключевые слова: малоновый диальдегид; саженцы березы повислой Betula pendula Roth.; саженцы тополя пирамидального Populus pyramidalis Roz:; о-ксилол; бенз(а)пирен; бутилацетат

\section{Введение}

В последние годы в Беларуси на фоне снижения общего объема выбросов загрязняющих веществ от стационарных и мобильных источников наблюдается рост количества выбросов в атмосферу от стационарных источников с 371,1 тыс. т в 2011 г. до 453,4 тыс. т в 2017 г. (Environmental protection .., 2018). При этом в результате функционирования отдельных промышленных предприятий в атмосферу поступают летучие органические соединения, удельный вес которых в общем объеме выбросов загрязняющих веществ по предприятию является наибольшим и которые способны оказывать определенное влияние на рост и развитие растительных организмов. Такую группу веществ составляют алканы, циклоалканы, непредельные и ароматические углеводороды, спирты, сложные эфиры. Одним из критериев адаптации растений к действию летучих органических соединений может служить интенсивность процессов перекисного окисления липидов (ПОЛ) как результат соотношения деструктивных окислительных процессов и активности антиоксидантной защиты растений. В настоящее время имеются результаты исследований влияния тяжелых металлов (Michailova, 2016), автотранспортного и промышленного загрязнения (Erofeeva, 2015; Neverova, 2010), оксидов азота, серы, углерода, взвешенных веществ (Curganova, Nesterov, 2014), температурного воздействия на накопление продуктов перекисного окисления липидов (Popov, 2010) в растениях. При этом наличие небольшого количества данных по эффектам влияния летучих органических токсикантов на показатели ПОЛ растений привлекает интерес к изучению дозовых зависимостей между содержанием малонового диальдегида (МДА) и количеством таких соединений. Кроме того, в настоящее время практически неизученными являются видовые особенности данного параметра у различных представителей древесных растений при росте в условиях воздействия летучих органических загрязнителей. В этой связи целью исследования явилось сравнительное изучение влияния различных доз летучих органических соединений (о-ксилола, бенз(а)пирена, бутилацетата) на содержание малонового диальдегида в саженцах древесных растений в задаваемых условиях эксперимента.

\section{Объекты и методы исследований}

Выбор саженцев березы повислой Betula pendula Roth. и тополя пирамидального Populus pyramidalis Roz. в качестве исследуемых объектов в экспериментальных условиях обусловлен широкой распространенностью растений в городских условиях. Использование о-ксилола, бутилацетата и их смеси обусловлено преобладающим количеством этих летучих органических соединений в выбросах отдельных промышленных предприятий города Гомеля (ОАО «Гомельский завод литья и нормалей») по сравнению с другими загрязняющими веществами. Что касается бенз(а)пирена, то, несмотря на невысокое наличие в выбросах предприятий теплоэнергетики (ТЭЦ-2), его использование в эксперименте связано с высокой токсичностью для живых организмов, способностью в небольших количествах вызывать значительный эффект, недостаточной изученностью эффектов влияния на процессы ПОЛ в листьях растений и возможностью проведения сравнительной оценки влияния полициклического ароматического углеводорода и одноядерных ароматических углеводородов (бензол, о-ксилол) на растительные организмы.

Листовые пластинки саженцев обрабатывали водными растворами углеводородов. Используемые дозы углеводородов рассчитывались исходя из установленных для атмосферного воздуха предельно допустимых концентраций (ПДК) загрязняющих веществ (Decree .., 2016). В соответствии с нормативами ПДК ксилолов в

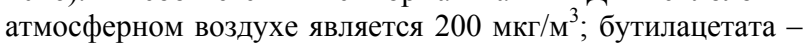

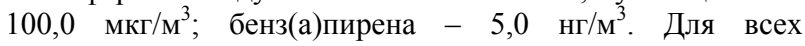
соединений, кроме бенз(а)пирена, использовали величину максимальной разовой ПДК; для бенз(а)пирена среднесуточную ПДК (Decree .., 2016).

В качестве контроля использовали необработанные растения; экспериментальными явились саженцы, обработанные водными растворами исследуемых 
соединений в следующих концентрациях: $0,0002-$ 0,06 мкг/мл о-ксилола, 0,000005-0,0015 нг/мл бенз(а)пирена, 0,0001-0,03 мкг/мл бутилацетата (бутилового эфира уксусной кислоты).

Всего в процессе эксперимента было использовано 5 различных доз вводимых соединений, что численно соответствует 1, 50, 10, 200 и 300 ПДК о-ксилола, бенз(а)пирена и бутилацетата в атмосферном воздухе.

Для выявления возможных эффектов совместного воздействия исследуемых соединений использовали смесь следующих концентраций: 0,01 мкг/мл бутилацетата + 0,02 мкг/мл о-ксилола; 0,02 мк/мл бутилацетата + 0,04 мкг/мл о-ксилола.

Обработка листовых пластинок саженцев осуществлялась путем опрыскивания водными растворами (по 50 мл водного раствора каждой дозы вводимого соединения).

Активность ПОЛ оценивали по количеству малонового диальдегида в результате цветной реакции с тиобарбитуровой кислотой. Содержание малонового диальдегида определяли с использованием спектрофотометра Shimadzu UV-2401 PC («Shimadzu», Япония) в максимуме поглощения при длине волны 532 нм и вычисляли как величину оптической плотности ( $\lambda 532-$ 630 нм), умноженную на коэффициент молярной экстинкции 21,285. Содержание малонового диальдегида выражали в нмоль/мг сырой массы.

Достоверность различий между содержанием малонового диальдегида в экспериментальных и контрольных пробах оценивали с помощью дисперсионного анализа. Математическую обработку цифрового материала выполняли с помощью M. Excel и Statistica.

С целью проведения сравнительной количественной оценки изменений содержания малонового диальдегида в условиях эксперимента проводили вычисления среднего значения разности содержания малонового диальдегида в начале и конце опыта в экспериментальных образцах при обработке каждым из используемых соединений.

\section{Результаты и их обсуждение}

Результаты определения содержания малонового диальдегида в листьях саженцев древесных растений в условиях эксперимента по обработке углеводородами и их смесью представлены в табл. 1-4 и на рис. 1.

\section{Таблица 1}

Содержание малонового диальдегида в саженцах древесных растений в условиях эксперимента после обработки о-ксилолом

\begin{tabular}{lcccc}
\hline \multirow{2}{*}{$\begin{array}{c}\text { Концентрация } \\
\text { раствора }\end{array}$} & \multicolumn{2}{c}{ Содержание малонового диальдегида, нмоль/мг сырой массы } \\
\cline { 2 - 4 } о-ксилола, мкг/мл & \multicolumn{2}{c}{$\begin{array}{c}\text { береза повислая } \\
\text { Betula pendula } \text { Roth. }\end{array}$} & \multicolumn{2}{c}{$\begin{array}{c}\text { тополь пирамидальный } \\
\text { Populus pyramidalis Roz. }\end{array}$} \\
\cline { 2 - 5 } & через одни сутки & через трое суток & через одни сутки & через трое суток \\
\hline Контроль & $3,46 \pm 0,11$ & $5,18 \pm 0,05$ & $4,46 \pm 0,01$ & $3,53 \pm 0,01$ \\
0,0002 & $9,80 \pm 0,02^{*}$ & $5,98 \pm 0,03 *$ & $5,50 \pm 0,01 *$ & $4,70 \pm 0,01^{*}$ \\
0,01 & $11,26 \pm 0,03 *$ & $10,98 \pm 0,03 *$ & $6,36 \pm 0,01 *$ & $5,21 \pm 0,02^{*}$ \\
0,02 & $11,98 \pm 0,01 *$ & $11,20 \pm 0,01^{*}$ & $6,47 \pm 0,02^{*}$ & $5,58 \pm 0,02^{*}$ \\
0,04 & $12,35 \pm 0,02^{*}$ & $11,34 \pm 0,05^{*}$ & $6,59 \pm 0,01^{*}$ & $5,78 \pm 0,01^{*}$ \\
0,06 & $18,70 \pm 0,01^{*}$ & $11,93 \pm 0,03^{*}$ & $7,99 \pm 0,01^{*}$ & $5,80 \pm 0,01^{*}$ \\
\hline
\end{tabular}

Примечание. Здесь и далее в табл. $2-4$ достоверные значения содержания малонового диальдегида при $\mathrm{p} \leq 0,05$ обозначены *.

Данные табл. 1-4 свидетельствуют о том, что обработка о-ксилолом, бенз(а)пиреном, бутилацетатом и их смесью является причиной увеличения содержания малонового диальдегида в экспериментальных образцах по сравнению с контрольными пробами практически при всех использованных дозах внесения.

При этом максимальная доза воздействия о-ксилола $(0,06$ мкг/мл) приводила к увеличению содержания малонового диальдегида в листьях саженцев березы повислой в 5,40 раза через одни сутки эксперимента и в 2,30 раза - через трое суток по сравнению с контролем; минимальная - в 2,83 раза и в 1,15 раза через одни и трое суток соответственно. Обработка листовых пластинок саженцев тополя пирамидального раствором о-ксилола явилась причиной менее резких изменений содержания малонового диальдегида: максимальная доза воздействия $(0,06$ мкг/мл) вызвала увеличение содержания малонового диальдегида в 1,79 раза через одни сутки эксперимента и в 1,64 раза - через трое суток по сравнению с контролем; минимальная - в 1,23 раза через одни сутки и в 1,33 раза через трое суток эксперимента.

Вызывают интерес результаты воздействия бенз(а)пирена (табл. 2), который является представителем полициклических ароматических углеводородов и характеризуется более высокой токсичностью по сравнению с о-ксилолом.

\section{Таблица 2}

Содержание малонового диальдегида в саженцах древесных растений в условиях эксперимента после обработки бенз(а)пиреном

\begin{tabular}{lcccc}
\hline \multirow{2}{*}{$\begin{array}{c}\text { Концентрация } \\
\text { раствора }\end{array}$} & \multicolumn{2}{c}{ Содержание малонового диальдегида, нмоль/мг сырой массы } \\
\cline { 2 - 4 } бенз(а)пирена, нг/мл & \multicolumn{2}{c}{ береза повислая } & \multicolumn{2}{c}{ тополь пирамидальный } \\
& \multicolumn{2}{c}{$\begin{array}{c}\text { Betula pendula } \text { Roth. } \\
\text { Populus pyramidalis } \text { Roz. }\end{array}$} \\
\cline { 2 - 5 } Контроль & через одни сутки & через трое суток & через одни сутки & через трое суток \\
0,000005 & $3,46 \pm 0,11$ & $5,18 \pm 0,05$ & $4,46 \pm 0,01$ & $3,53 \pm 0,01$ \\
0,00025 & $15,65 \pm 0,01^{*}$ & $14,27 \pm 0,20^{*}$ & $4,53 \pm 0,03^{*}$ & $2,72 \pm 0,01^{*}$ \\
0,0005 & $16,36 \pm 0,02^{*}$ & $16,35 \pm 0,08^{*}$ & $5,17 \pm 0,01^{*}$ & $3,35 \pm 0,02^{*}$ \\
0,001 & $17,10 \pm 0,04^{*}$ & $16,74 \pm 0,13^{*}$ & $5,63 \pm 0,01^{*}$ & $3,72 \pm 0,03^{*}$ \\
0,0015 & $17,27 \pm 0,03^{*}$ & $19,11 \pm 0,02^{*}$ & $5,72 \pm 0,01^{*}$ & $3,92 \pm 0,01^{*}$ \\
\hline
\end{tabular}

Через одни сутки эксперимента с раствором бенз(а)пирена содержание малонового диальдегида в листьях березы повислой при воздействии максимальной дозы $(0,0015$ нг/мл) увеличилось по сравнению с контролем в 5,35 раза, через трое суток - в 4,88 раза. Минимальная доза воздействия $(0,000005$ нг/мл) 
приводила к росту содержания малонового диальдегида в 4,52 раза через одни сутки после обработки и в 2,75 раза через трое суток. У тополя пирамидального, который характеризуется достаточной устойчивостью к воздействию загрязнителей, как и в опыте с раствором о-ксилола, активность окислительных процессов была менее интенсивной, что при воздействии максимальной дозы (0,0015 нг/мл) через одни сутки привело к росту МДА по сравнению с контролем в 1,52 раза, через трое суток - в 1,19 раза. Минимальная доза воздействия (0,000005 нг/мл) приводила к незначительному росту содержания малонового диальдегида через одни сутки (в 1,02 раза), а через трое суток рост содержания МДА отмечался только при воздействии растворов с концентрацией 0,00050,0015 нг/мл. Следует отметить, что по сравнению с о-ксилолом в наших исследованиях бенз(а)пирен вызывал менее активные процессы перекисного окисления липидов биологических мембран клеток, что особенно было выражено у саженцев тополя пирамидального.

Бутилацетат (бутиловый эфир уксусной кислоты) наряду с этилацетатом всегда присутствовал в выбросах отдельных промышленных предприятий, однако в последние годы вследствие изменений в технологическом процессе наблюдается довольно значительный рост объема выбросов бутилацетата в атмосферу. В нашем эксперименте обработка бутилацетатом листовых пластинок саженцев березы повислой приводила к росту содержания малонового диальдегида при максимальной дозе воздействия (0,03 мкг/мл) в 3,77 раза через одни сутки и в 1,78 раза - через трое суток (табл. 3 ).

\section{Таблица 3}

Содержание малонового диальдегида в саженцах древесных растений в условиях эксперимента после обработки бутилацетатом

\begin{tabular}{|c|c|c|c|c|}
\hline \multirow{3}{*}{$\begin{array}{c}\text { Концентрация } \\
\text { раствора } \\
\text { бутилацетата, мкг/мл }\end{array}$} & \multicolumn{4}{|c|}{ Содержание малонового диальдегида, нмоль/мг сырой массы } \\
\hline & \multicolumn{2}{|c|}{$\begin{array}{c}\text { береза повислая } \\
\text { Betula pendula Roth. }\end{array}$} & \multicolumn{2}{|c|}{$\begin{array}{l}\text { тополь пирамидальный } \\
\text { Populus pyramidalis Roz. }\end{array}$} \\
\hline & через одни сутки & через трое суток & через одни сутки & через трое суток \\
\hline Контроль & $3,46 \pm 0,11$ & $5,18 \pm 0,05$ & $4,46 \pm 0,01$ & $3,53 \pm 0,01$ \\
\hline 0,0001 & $10,70 \pm 0,02 *$ & $7,52 \pm 0,02 *$ & $4,90 \pm 0,01 *$ & $5,21 \pm 0,01 *$ \\
\hline 0,005 & $10,75 \pm 0,01 *$ & $7,72 \pm 0,02 *$ & $6,23 \pm 0,01 *$ & $6,0 \pm 0,02 *$ \\
\hline 0,01 & $12,22 \pm 0,01 *$ & $7,89 \pm 0,06^{*}$ & $6,34 \pm 0,02 *$ & $7,09 \pm 0,01 *$ \\
\hline 0,02 & $12,32 \pm 0,05^{*}$ & $8,94 \pm 0,03 *$ & $7,05 \pm 0,02 *$ & $7,40 \pm 0,02 *$ \\
\hline 0,03 & $13,05 \pm 0,05^{*}$ & $9,21 \pm 0,02 *$ & $7,37 \pm 0,01 *$ & $7,77 \pm 0,02 *$ \\
\hline
\end{tabular}

Минимальная доза воздействия (0,0001 мкг/мл) вызывала рост содержания малонового диальдегида у березы повислой в 3,09 раза через одни сутки и в 1,45 раза - через трое суток после обработки.

Обработка листовых пластинок саженцев тополя пирамидального привела к менее интенсивному росту содержания МДА по сравнению с контролем: при максимальной дозе воздействия $(0,03$ мкг/мл) в 1,65 раза через одни сутки и в 2,20 раза - через трое суток; при минимальной дозе - в 1,10 раза через одни сутки эксперимента, в 1,48 раза - через трое суток.

Результаты кластерного анализа содержания малонового диальдегида в саженцах древесных растений за период эксперимента представлены на рис. 1 (двухвходовый кластерный анализ).

Данные рис. 1 свидетельствуют о том, что через одни сутки после обработки накопление повышенного количества малонового диальдегида в листьях саженцев являлось результатом влияния о-ксилола и бенз(а)пирена, тогда как интенсивность процессов ПОЛ через трое суток эксперимента повышалась в случае обработки бутилацетатом и бенз(а)пиреном.

Для оценки влияния смеси летучих органических соединений на интенсивность развития процессов ПОЛ был проведен эксперимент по совместному воздействию на листовые пластинки исследуемых саженцев древесных растений смеси бутилацетата с о-ксилолом, наличие которой характерно для выбросов промышленных предприятий.

Результаты проведенного эксперимента показали возможность используемой смеси вызывать более интенсивные процессы ПОЛ и увеличение содержания малонового диальдегида по сравнению с контрольными пробами через одни и трое суток после обработки (табл. 4).

\section{Таблица 4}

Содержание малонового диальдегида в саженцах древесных растений в условиях эксперимента после обработки смесью бутилацетата и о-ксилола

\begin{tabular}{|c|c|c|}
\hline \multirow[t]{2}{*}{ Варианты опыта } & \multicolumn{2}{|c|}{$\begin{array}{c}\text { Содержание малонового диальдегида, } \\
\text { нмоль/мг сырой массы }\end{array}$} \\
\hline & через одни сутки & через трое суток \\
\hline \multicolumn{3}{|c|}{ Береза повислая Betula pendula Roth., смесь бутилацетат + о-ксилол } \\
\hline Контроль & $3,46 \pm 0,11$ & $5,18 \pm 0,05$ \\
\hline 0,01 мкг/мл +0,02 мкг/мл & $11,08 \pm 0,03 *$ & $6,88 \pm 0,05 *$ \\
\hline 0,02 мкг/мл +0,04 мкг/мл & $11,16 \pm 0,04 *$ & $10,04 \pm 0,01 *$ \\
\hline \multicolumn{3}{|c|}{ Тополь пирамидальный Populus pyramidalis Roz., смесь бутилацетат + о-ксилол } \\
\hline 0,01 мкг/мл +0,02 мкг/мл & $7,83 \pm 0,02 *$ & $7,31 \pm 0,02 *$ \\
\hline 0,02 мкг/мл +0,04 мкг/мл & $8,88 \pm 0,01 *$ & $8,06 \pm 0,03 *$ \\
\hline
\end{tabular}

Так, обработка смесью листовых пластинок саженцев березы повислой приводила к росту содержания малонового диальдегида при максимальной дозе воздействия $(0,02$ мкг/мл бутилацетата $+0,04$ мкг/мл о-ксилола) в 3,22 раза через одни сутки и в 1,94 раза через трое суток; при минимальной дозе $(0,01$ мкг/мл бутилацетата + 0,02 мкг/мл о-ксилола) - в 3,20 раза через одни сутки и в 1,33 раза - через трое суток. У тополя 
Саженцы березы повислой Betula pendula Roth.

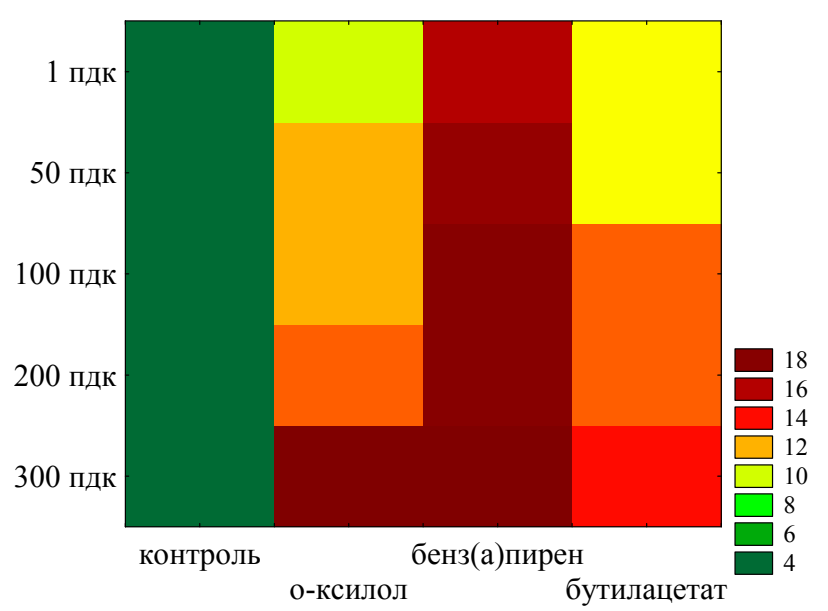

Через одни сутки после обработки

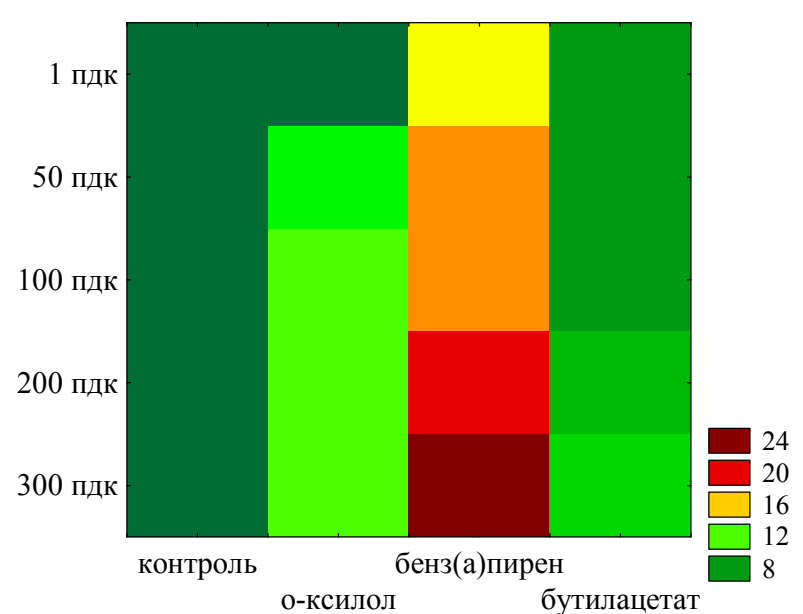

Через трое суток после обработки

Саженцы тополя пирамидального Populus pyramidalis Roz.

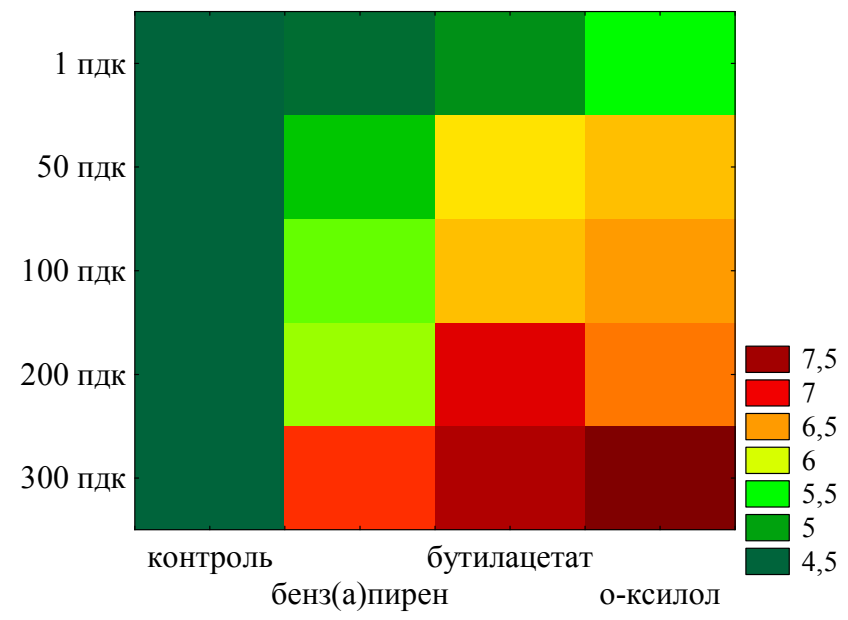

Через одни сутки после обработки

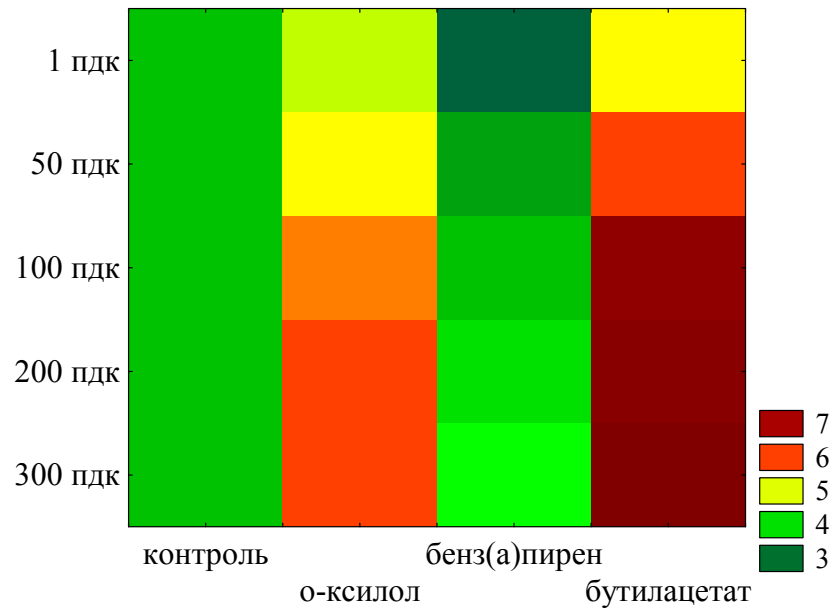

Через трое суток после обработки

Рис. 1. Результаты кластерного анализа содержания малонового диальдегида (в нмоль/мг сырой массы) в саженцах древесных растений

пирамидального содержание МДА при воздействии максимальной дозы увеличилось в 1,99 раза через одни сутки после обработки, через трое суток - в 2,29 раза; при минимальной дозе - в 1,76 раза через одни сутки и в 2,07 раза - через трое суток.

Следует отметить, что совместная обработка листовых пластинок саженцев березы повислой смесью бутилацетата и о-ксилола обусловила возможность этих соединений усиливать токсическое действие друг друга по сравнению с их действием по одному, за исключением о-ксилола через трое суток после обработки смесью в максимальной дозе. $\mathrm{y}$ тополя пирамидального используемые соединения в смеси проявляли себя в качестве антагонистов и в отличие от березы повислой бутилацетат в смеси ослаблял токсическое действие о-ксилола по сравнению с его влиянием в виде одиночного раствора, а о-ксилол ослаблял действие бутилацетата.

Достоверность различий между содержанием малонового диальдегида в листовых пластинках экспериментальных и контрольных саженцев древесных растений оценивали с помощью дисперсионного анализа.

Результаты дисперсионного анализа комплексов, состоящих из содержания малонового диальдегида в экспериментальных пробах и контроля, свидетельствуют о том, что значение F-критерия превышает F-критическое для всех исследованных образцов во всех случаях после обработки одиночными соединениями и смесью $\left(\mathrm{F}_{\text {фактич. }}=\right.$ $13,76 \div 488,76$ для березы повислой; $\mathrm{F}_{\text {фактич. }}=8,74 \div$
956,26 для тополя пирамидального; $\mathrm{F}_{\text {критич. }}(1,6)=5,99$ при $\mathrm{p} \leq 0,05)$.

Сравнение комплексов дисперсий содержания МДА через 1 и 3 суток в эксперименте позволило установить достоверность их различий с течением времени действия обработки без учета контрольных проб $\left(\mathrm{F}_{\text {фактич. }}=10,70 \div\right.$ 374,15 для березы повислой; $\mathrm{F}_{\text {фактич. }}=6,76 \div 347,73$ для тополя пирамидального; $\mathrm{F}_{\text {критич. }}(1,6)=5,99$ при $\left.\mathrm{p} \leq 0,05\right)$. Исключение составило содержание малонового диальдегида в листьях березы повислой после обработки раствором бенз(а)пирена с концентрацией 0,00025 нг/мл. Полученные результаты свидетельствуют о том, что изменение содержания малонового диальдегида, вызванное таким влиянием, незначительно в течение периода эксперимента и носит недостоверный характер. В остальных случаях воздействие использованных соединений по одному и в смеси достоверно проявлялось и различалось на протяжении одних и трех суток после обработки.

С целью проведения количественной оценки влияния использованных ароматических углеводородов и сложного эфира на содержание малонового диальдегида в листьях саженцев древесных растений нами был проведен расчет различий количества МДА между экспериментальными и контрольными значениями, а также между пробами, измеренными через одни и трое суток после обработки.

Результаты кластерного анализа изменений содержания малонового диальдегида в саженцах 
древесных растений по сравнению с контролем представлены на рис. 2 (кластерный анализ методом иерархической классификации).

Данные, представленные на рис. 2, свидетельствуют о том, что у березы повислой через одни сутки после обработки один кластер соединений, вызывающих достаточно значительные изменения содержания МДА по сравнению с контролем, образовали о-ксилол и бутилацетат (по сравнению с контролем содержание МДА возросло на 6,34-15,23 нмоль/мг сырой массы листа).

Через одни сутки после обработки

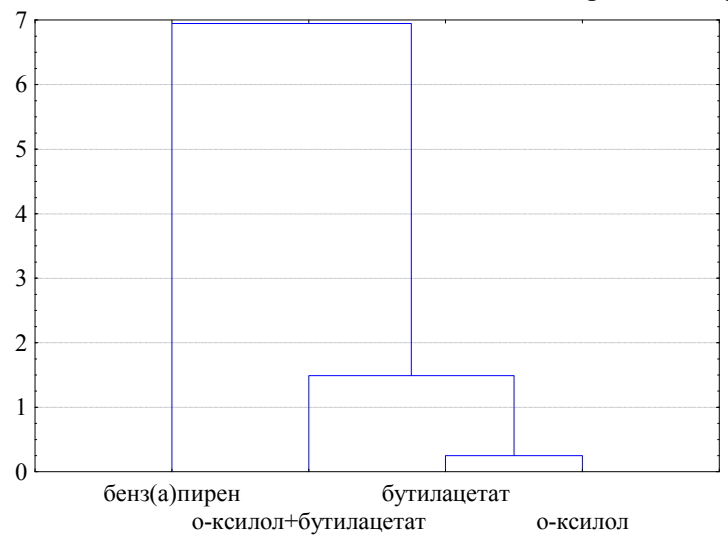

Береза повислая Betula pendula Roth

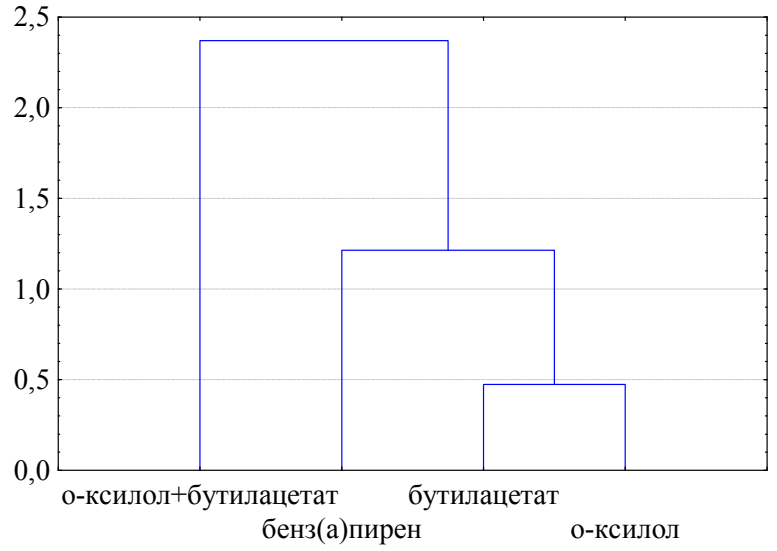

Тополь пирамидальный Populus pyramidalis Roz.

Через трое суток после обработки

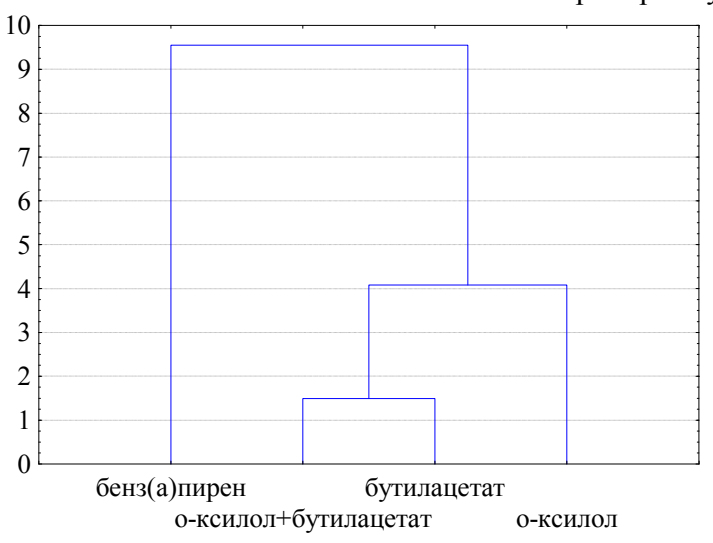

Береза повислая Betula pendula Roth.

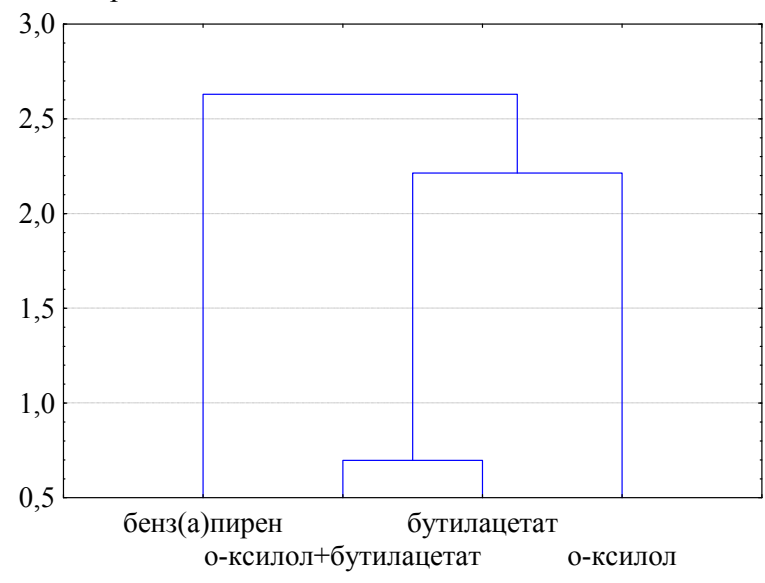

Тополь пирамидальный Populus pyramidalis Roz.

Рис. 2. Дендрограммы изменений содержания малонового диальдегида в саженцах древесных растений по сравнению с контролем

Обработка бенз(а)пиреном явилась причиной максимальных различий по отношению к контрольным пробам (на 12,19-15,06 нмоль/мг сырой массы); смесью бутилацетата с о-ксилолом - минимальных в опыте с березой повислой (на 7,62-7,70 нмоль/мг сырой массы). Через трое суток один кластер минимально влияющих соединений сформировали бутилацетат и смесь бутилацетата с о-ксилолом (по сравнению с контролем содержание МДА возросло на 1,70-4,86 нмоль/мГ сырой массы); о-ксилол вызвал более интенсивные изменения (на 0,80-6,74 нмоль/мг сырой массы) и бенз(а)пирен максимальные (на 9,09-20,09 нмоль/мг сырой массы).

У тополя пирамидального дендрограммы изменений содержания МДА в опыте с используемыми летучими органическими соединениями имели тот же вид, за исключением периода первых суток после обработки бенз(а)пиреном и смеси бутилацетата с о-ксилолом: у тополя пирамидального в отличие от березы повислой бенз(а)пирен, напротив, вызывал минимальные изменения по сравнению с контролем, а смесь бутилацетата с о-ксилолом - максимальные.
В результате выявления различий между пробами, измеренными через одни и трое суток после обработки, было получено, что влияние о-ксилола, бутилацетата и смеси бутилацетата с о-ксилолом на содержание малонового диальдегида у березы повислой Betula pendula Roth. проявлялось в виде уменьшения содержания МДА и интенсивности процессов ПОЛ через трое суток эксперимента, тогда как в течение первых суток после воздействия ответная реакция растений выражалась в накоплении продуктов ПОЛ (рис. 3).

Бенз(а)пирен, в отличие от о-ксилола, бутилацетата и их смеси, у березы повислой явился причиной более высокого содержания МДА через трое суток после обработки.

У тополя пирамидального характер влияния о-ксилола и смеси бутилацетата с о-ксилолом с течением времени эксперимента был аналогичным березе повислой и выражался в накоплении продуктов ПОЛ через одни сутки после обработки. Что касается действия бенз(а)пирена и бутилацетата, то их использование обусловило противоположные березе повислой эффекты: повышенное количество малонового диальдегида через 

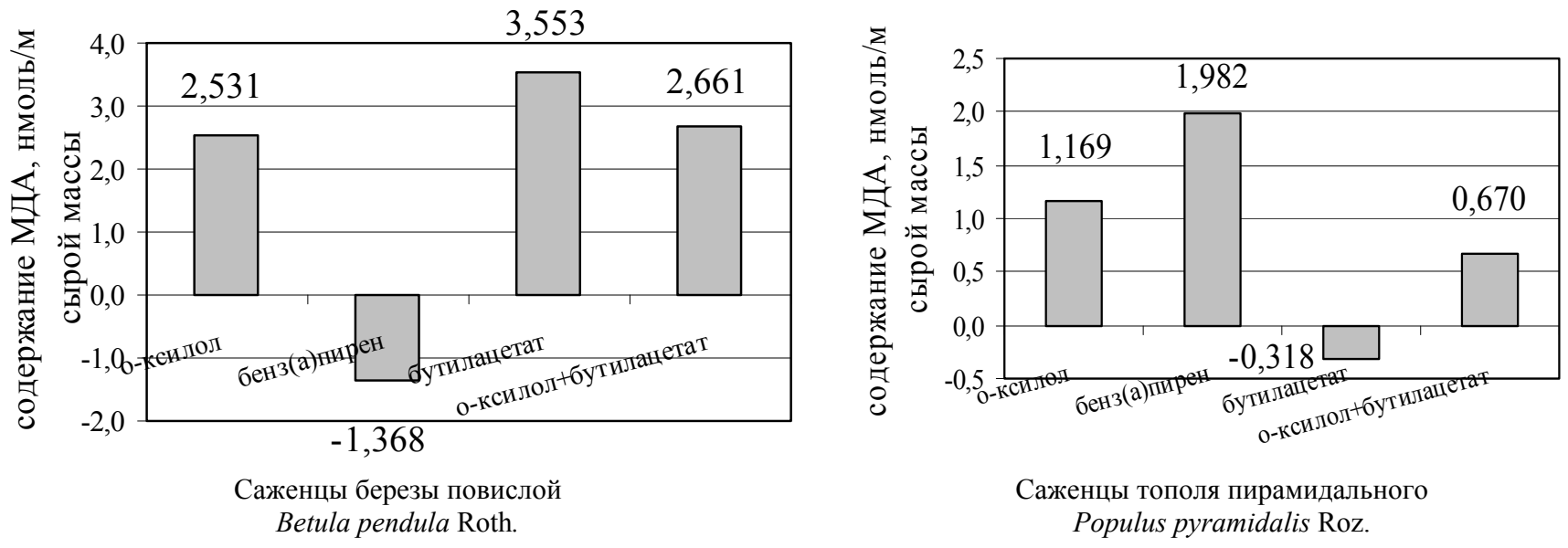

Рис. 3. Изменение содержания малонового диальдегида в саженцах древесных растений за период эксперимента (одни - трое суток)

одни сутки после обработки бенз(а)пиреном и бутилацетата - через трое суток эксперимента.

\section{Выводы}

Результаты эксперимента по обработке листовых пластинок саженцев древесных растений городской среды летучими углеводородами и их смесью свидетельствуют о том, что влияние о-ксилола, бутилацетата и смеси бутилацетата с о-ксилолом на содержание малонового диальдегида у березы повислой Betula pendula Roth. в течение первых суток после воздействия проявлялось в накоплении продуктов ПОЛ, тогда как через трое суток эксперимента ответная реакция растений в этом случае выражалась в виде уменьшения содержания МДА и интенсивности процессов ПОЛ. Бенз(а)пирен у березы повислой явился причиной более высокого содержания МДА через трое суток после обработки.

У тополя пирамидального характер влияния о-ксилола и смеси бутилацетата с о-ксилолом с течением времени эксперимента был аналогичным березе повислой и выражался в накоплении продуктов ПОЛ через одни сутки после обработки. Бенз(а)пирен явился причиной повышенного содержания малонового диальдегида через одни сутки после обработки, бутилацетат - через трое суток опыта.

Совместная обработка листовых пластинок саженцев березы повислой смесью бутилацетата и о-ксилола обусловила возможность этих соединений усиливать токсическое действие друг друга по сравнению с их действием по одному, за исключением о-ксилола через трое суток после обработки смесью в максимальной дозе. У тополя пирамидального в отличие от березы повислой бутилацетат в смеси ослаблял токсическое действие о-ксилола по сравнению с его влиянием в виде одиночного раствора, а о-ксилол ослаблял действие бутилацетата.

В целом у исследуемых древесных саженцев в один кластер наиболее сильно действующих соединений на процессы перекисного окисления липидов мембран по сравнению с контролем могут быть отнесены бенз(а)пирен (у березы повислой), бутилацетат и смесь бутилацетата с о-ксилолом (у тополя пирамидального).

\section{References}

Erofeeva, E. A., Shapovalova, K. V. (2015). Mnogoletnii sravnitelnii analis ustoichivosti Betula pendula (Betulaceae,
Fagales) i Tilia cordata (Malvaceae, Malvales) k avtotransportnomu zagrazneniu [Long-term comparative analysis of Betula pendula (Betulaceae, Fagales) and Tilia cordata (Malvaceae, Malvales) resistance to motor pollution]. Povolgski ekologicheski gurnal, 4, 390-399 (in Russian).

Kurganova, L. N. Perekisnoe okislenie lipidov - odna iz vozmognix component bistroi reaksii na stress [Lipid peroxidation is one of the possible components of a quick response to stress.]. Electronnii resurs: http://www.www.unn.ru. (in Russian).

Mixailova, I. D., Lukatkin, A. S. (2016). Perekisnoe okislenie lipidov $\mathrm{v}$ rasteniax ogurtsa i redisa pri deistvii tjagelix metallov [Lipid peroxidation in cucumber and radish plants under the action of heavy metals]. Izvestia Sarat. Un-ta. Ser. Ximia, Biologoa, Ekologia, 16, 206-210 (in Russian).

Nesterov, V. N. i dr. (2014). Perekisnoe okislenie lipidov dikorastuschix galofilov $\mathrm{v}$ usloviax Prieltonia [Lipids peroxidation of wild halophiles in the Elton conditions]. Izvestia Samar. Nauchnogo sentra RAN, 16, 299-303 (in Russian)

Neverova, O. A., Legoschina, O. M., Bikov, A. A. (2010). Otsenka intensivnisti okislitelnich protsesev $\mathrm{u}$ drevesnix rastenii $\mathrm{v}$ zone deistvia promishlenix vibrisov [Assessment of the intensity of oxidative processes in woody plants in the industrial emissions area]. Izvestia Samar. Nauchnogo sentra RAN, 12, 776-779 (in Russian).

Oxrana okrugauschei sredi v Respublike Belarus (2018). [Environmental protection of Belarus Republic], Statisticheskiy sbornik. Minsk (in Russian) (in Russian).

Popov, B. N., Antipina, O. V., Trunova, T. I. (2010). Perekisnoe okislenie lipidov pri nizkotemperaturnoi adaptatsii listev i kornei teplolubivix rastenii tabaka [Lipid peroxidation in the low-temperature adaptation of heat-loving tobacco plants leaves and roots]. Fiziologia rastenii, 1, 153-156 (in Russian).

Postanovlenie Ministerstva zdravooxranenia Respubliki Belarus (2016). «Ob utvergdenii i vvedenii $\mathrm{v}$ deistvie normativov predelno dopustimix konsentrasii zagraznauschix veschestv $\mathrm{v}$ atmosfermom vozduxe i orientirovochno bezopasnix urovnei vozdeistvia zagraznauschix veschestv $\mathrm{v}$ atmosfernom vozduche naselennix punktov $\mathrm{i}$ mest massovogo otdixa naselenia» № 113 [Decree of Republic of Belarus Health Ministry «On the approval and enactment of standards for pollutants maximum permissible concentrations in the air and tentatively safe levels of exposure to pollutants in the air of settlements and public recreation places» № 113] (in Russian). 